\title{
The Gray Hawk (Buteo nitidus) is Two Species
}

Author(s): Brian A. Millsap, Sergio H. Seipke and William S. Clark

Source: The Condor, 113(2):326-339. 2011.

Published By: Cooper Ornithological Society

URL: http://www.bioone.org/doi/full/10.1525/cond.2011.100089

BioOne (www.bioone.org) is a nonprofit, online aggregation of core research in the biological, ecological, and environmental sciences. BioOne provides a sustainable online platform for over 170 journals and books published by nonprofit societies, associations, museums, institutions, and presses.

Your use of this PDF, the BioOne Web site, and all posted and associated content indicates your acceptance of BioOne's Terms of Use, available at www.bioone.org/page/terms of use.

Usage of BioOne content is strictly limited to personal, educational, and non-commercial use. Commercial inquiries or rights and permissions requests should be directed to the individual publisher as copyright holder. 


\title{
THE GRAY HAWK (BUTEO NITIDUS) IS TWO SPECIES
}

\author{
Brian A. Millsap ${ }^{1,4}$, Sergio H. Seipke ${ }^{2}$, and William S. Clark ${ }^{3}$ \\ ${ }^{1}$ U.S. Fish and Wildlife Service, P. O. Box 1306, Albuquerque, NM 87103 \\ ${ }^{2}$ Calle $57 n^{\circ} 1230$ “A," La Plata, 1900, Buenos Aires, Argentina \\ ${ }^{3} 2301$ South Whitehouse Circle, Harlingen, TX 78550
}

\begin{abstract}
We compared the plumage, morphology, and the alarm call of two taxa of the Gray Hawk (Buteo nitidus) from north and south of a distributional gap in the species' range in Costa Rica. We found all age and sex classes completely distinguishable on the basis of several discrete plumage features. Three of four age and sex classes were diagnosably distinct by measurements of external morphology alone, and the two taxa had diagnosably different alarm calls. On the basis of the level and stability of morphological differentiation, and consistent with prior work suggesting substantial genetic differentiation between the two taxa, we recommend they be recognized as full species, B. nitidus, the Gray-lined Hawk, south of the distributional gap in Costa Rica, and B. plagiatus, the Gray Hawk, north of the gap.
\end{abstract}

Key words: Buteo nitidus, Buteo plagiatus, Gray Hawk, Gray-lined Hawk, species, taxonomy.

\section{Buteo nitidus Comprende Dos Especies}

Resumen. Comparamos el plumaje, la morfología y la voz de alarma de dos taxones de Buteo nitidus distribuidos respectivamente al norte y al sur de un hiato en la distribución de la especie ubicado en Costa Rica. Encontramos que todas las clases de edad y sexo pueden distinguirse completamente sobre la base de varias características discretas del plumaje. Fue posible diferenciar en forma diagnóstica tres de cuatro clases de edad y sexo sobre la base de medidas de la morfología externa. Ambos taxones pudieron diferenciarse en forma diagnóstica sobre la base de sus voces de alarma. Teniendo en cuenta el nivel y la estabilidad de las diferencias morfológicas, y en concordancia con trabajos previos que sugieren una diferenciación genética sustancial entre los dos taxones, recomendamos que éstos sean reconocidos como dos especies diferentes: B. nitidus, distribuido al sur del hiato en Costa Rica, y B. plagiatus, al norte de éste.

\section{INTRODUCTION}

The Gray Hawk (Buteo nitidus, hereafter B. n. nitidus) was described by Latham (1790) as Falco nitidus, on the basis of a specimen from French Guiana. Subsequently, Schlegel (1862) described Asturina plagiata (hereafter B. n. plagiatus) on the basis of a specimen from Veracruz, Mexico. Schlegel considered B. n. plagiatus a species distinct from B. n. nitidus because it was larger, had more robust tarsi and feet, and had more tail bands. In their review of North American birds, Baird et al. (1874) concluded the two taxa were climatic races of the same species, and this view has largely prevailed since (Bierregaard 1994, Ferguson-Lees and Christie 2001, American Ornithologists' Union [AOU] 2008). However, not all ornithologists have agreed with this treatment. Miller and Griscom (1921), van Rossem (1930), and Sibley and Monroe (1990) treated the taxa as species. Friedmann (1950), Streseman and Amadon (1979), and the AOU (1983) treated them as conspecific but commented that they might be full species. Johnson and Peeters (1963), in their detailed analysis of plumage variation of woodland hawks, concluded that "striking differences between the [northern and southern] races [of the Gray Hawk] are obvious." These authors noted that the plumage discontinuity coincides with a gap in the species' distribution in Costa Rica, which is also described by Stiles and Skutch (1989). Blake (1977) presented measurement data for all recognized subspecies of the Gray Hawk, but he did not analyze the measurement differences between taxa quantitatively. He treated B. n. nitidus and plagiatus as conspecific but noted that many consider them separate species. Millsap (1986) and Riesing et al. (2003) evaluated morphological and genetic differences between the two taxa, respectively, and concluded they differ markedly.

Despite these various past treatments, there is no comprehensive published analysis of plumage, measurement, and vocal data for the Gray Hawk on which a decision regarding the species-level status of the two taxa can be based (Banks et al. 2006). In this paper we examine and compare plumages, morphology, and vocalizations of $B . n$. nitidus and $B . n$. plagiatus to address this shortcoming. Consistent with findings of previous investigators, particularly the recent mitochondrial DNA (mtDNA) work of Riesing et al. (2003), we found that the taxa are diagnosably distinct. On the basis of our review and analyses, we recommend that these taxa be treated as separate species.

Manuscript received 1 May 2010; accepted 1 December 2010.

${ }^{4}$ E-mail: brian_a_millsap@fws.gov

The Condor, Vol. 113, Number 2, pages 326-339. ISSN 0010-5422, electronic ISSN 1938-5422. @ 2011 by The Cooper Ornithological Society. All rights reserved. Please direct all requests for permission to photocopy or reproduce article content through the University of California Press's Rights and Permissions website, http://www.ucpressjournals.com/ reprintInfo.asp. DOI: $10.1525 /$ cond.2011.100089 


\section{METHODS}

We examined the plumages and took measurements of 405 specimens of $B . n$. nitidus and B. n. plagiatus in the collections of the American Museum of Natural History (AMNH), National Museum of Natural History (USNM), Museum of Comparative Zoology at Harvard (MCZ), University of Kansas Museum of Natural History (KMNH), Delaware Museum of Natural History (DMNH), and the Field Museum of Natural History (FMNH) (Appendix A). For analyses, we assigned specimens from localities south of the species' distributional gap in Costa Rica to B. $n$. nitidus $(n=141)$ and those from localities north of the gap to $B$. $n$. plagiatus $(n=264)$. Our sample included a full representation of described subspecies, although none of these subspecies are likely diagnosably distinct at levels that warrant such recognition (Millsap 1986). Blake (1977) recognized three subspecies across the range of what we call $B$. n. nitidus, and our sample of this taxon included 39 specimens from the range he ascribed to B. n. blakei, 81 from his range for B. n. nitidus, and 21 from the range he ascribed to $B$. $n$. pallidus. Blake (1977) only recognized one subspecies from the range of our $B$. n. plagiatus, but Miller and Griscom (1921) described B. n. micrus from Central America, and van Rossem (1930) described B. n. maximus from northern Mexico and the southwestern United States. Our sample included 95 individuals from the range van Rossem (1930) ascribed to B. n. maximus and 66 from the range Miller and Griscom (1921) ascribed to B. n. micrus. Locality information for two specimens was insufficient for the individuals to be assigned to a subspecies.

We did not take all measurements on every specimen, so sample sizes for the different variables and analyses vary. On adult specimens, we noted the presence or absence of distinctive barring on the crown, nape, back, scapulars, and rump; we measured the width of the second (proximal) white band across the right central rectrix (perpendicular to the shaft) and the width of the rectrix, and counted the number of rectrices on the right side of the tail (six total) with unbroken second and third white bands (bird topography follows Blake [1956] throughout). On juveniles, we recorded the general color pattern of the plumage on the crown (primarily light, streaked, or dark) and primaries (light interspaces on webs of outer primaries primarily white or primarily buff) and the pattern of markings on the breast, belly, and thighs (streaked, barred, spotted, or unmarked). Additionally, we counted the number of dark bands on the dorsal surface of the tail. We selected these plumage characters (after examination of $>100$ specimens) because we found them to be homogeneous within local populations but variable over the range of the species.

Measurements taken were (1) culmen length (chord from distal rim of cere to tip of bill); (2) maxilla depth (height from distal rim of cere at the culmen to the commissure); (3) wing length (flattened); (4) tarsus length (from the posterior center of the tibiotarsal-tarsometatarsal joint to the base of the center toe at the flexion point); (5) tarsus width (anterior-posterior width at the junction of the third and fourth distal undivided scutes); (6) hind claw (chord); (7) center toe (length, excluding claw); and (8) tail (length between central rectrices from point of insertion to tip). Specimens on which all eight measurements could not be obtained were excluded from multivariate analyses. In addition, we measured the extension of the primaries beyond the secondaries on folded wings of 61 specimens in the collection of the FMNH.

We have observed both taxa in their respective ranges during $>1000 \mathrm{hr}$ of field work and have taken $>450$ photographs of both taxa. We studied these photographs and others provided to us by other photographers to develop field marks to distinguish the taxa in the field. We excerpted and include here the color illustration depicting field marks of both taxa, prepared by J. Schmitt for a projected field guide to the raptors of Mexico and Central America (Fig. 1).

Buteo n. nitidus and B. n. plagiatus have two primary vocalizations, a three-note call used primarily during the breeding season and a single-note alarm call (Bibles et al. 2002). There are few recorded examples of the three-note call, so we focused our analysis on the single-note alarm call. Using Raven Pro 1.3 (http://www.birds.cornell.edu/brp/raven/ ravenversions.html) with default settings, we examined all digitized recordings of $B . n$. nitidus and $B$. n. plagiatus alarm calls available at http://www.xeno-canto.org/ (XC; last visited 5 September 2010) and provided to us by staff at the Macaulay Library (ML) at Cornell University (http://macaulaylibrary. org/index.do, last visited 5 September 2010). We eliminated some calls that we suspect were misidentified, that were of poor quality, or that were obviously atypical. For the remaining 25 calls of $B$. n. nitidus and 8 of B. n. plagiatus (Appendix $B)$, we selected the first typical alarm note that was suitable for numerical analysis in each recording, and we created a spectrogram for the piece of each selection that contained the full note. We created spectrograms with the short-time Fourier transformation in Raven Pro 1.3 with the time scale set to $3.05 \mathrm{sec}$, frequency position to $500 \mathrm{~Hz}$, and frequency scale to $11000 \mathrm{~Hz}$ per line. We increased brightness and contrast to $60 \%$ to $75 \%$ to improve accuracy in identifying the start and end points of the notes. On each spectrogram we selected a rectangle containing the full length of the note and leaving out any trailing echoes, bracketing the range from 1 to $10 \mathrm{kHz}$ $( \pm 25 \mathrm{~Hz}$ ) to limit the effect of different frequency responses from microphones of varying qualities. For each note we measured the following characteristics: (1) peak frequency, the frequency of peak power within the selection; (2) time, the duration of the audible part of the note; (3) center frequency, the frequency that divided the selection into two frequency intervals of equal energy; (4) bandwidth of the interquartile range, the difference between the frequencies of the first and 


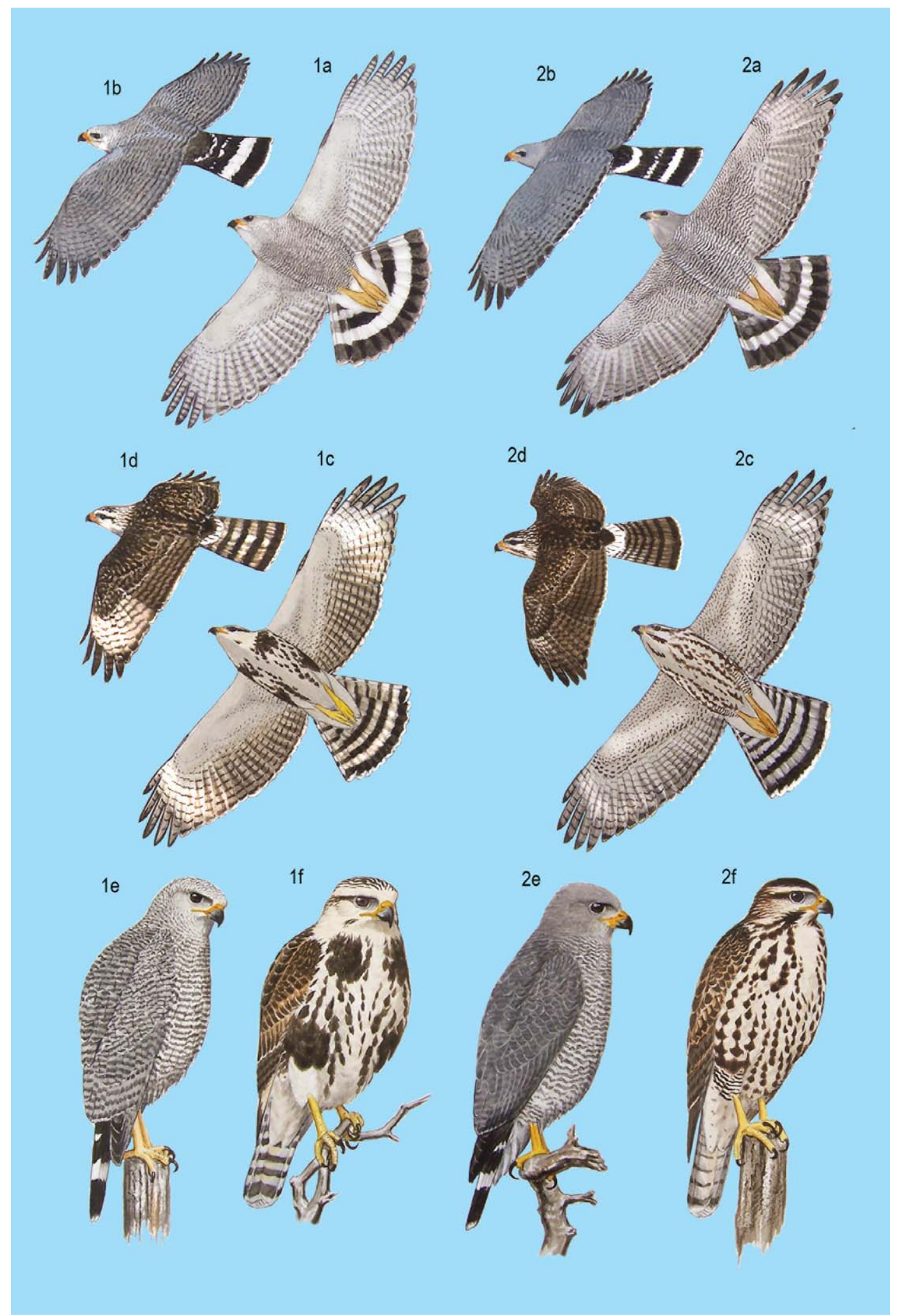

FIGURE 1. Plumage differences between $B . n$. nitidus and $B . n$. plagiatus (see Table 1 for a description of major differences) where 1 is B. n. nitidus; 2 is B. n. plagiatus; a, adult in flight, ventral view; b, adult in flight, dorsal view; c, juvenile in flight, ventral view; d, juvenile in flight, dorsal view; e, adult, perched; $f$, juvenile, perched. 
third quartiles (the frequencies that divided the selection into two ranges containing $25 \%$ and $75 \%$, and $75 \%$ and $25 \%$, of the energy in the selection, respectively); (5) duration of the interquartile range, the difference between the times of the first and third quartiless (the points in time that divided the selection into two ranges containing $25 \%$ and $75 \%$, and $75 \%$ and $25 \%$, of the energy in the selection, respectively); and (6) pitch-drop position, the proportion of the note emitted before there was a visible, sudden drop in pitch (scored as 0 to 1.0, with 0 for notes with no sudden drop in pitch).

\section{STATISTICAL ANALYSES}

Females of $B$. n. nitidus and B. n. plagiatus are substantially larger than males (Snyder and Wiley 1976), so we analyzed measurements for sexes separately. Preliminary analysis indicated that tail lengths of adults and juveniles differ, therefore we treated the ages separately in analyses that included this character. We evaluated most plumage characters qualitatively but compared measured tail-pattern characters with box plots, compared means with one-way analysis of variance (ANOVA), and included them in the discriminant function analysis (DFA; see below). For all parametric statistical tests we transformed proportions with the angular transformation (Sokal and Rohlf 1981), counts with the square-root transformation, and confirmed the normality of distributions of other characters by the Kolmogorov-Smirnov test (SYSTAT 2009). On the basis of the latter tests, we log-transformed tarsus length, hind claw, and toe measurements.

We analyzed the primary-projection measurements with a three-way ANOVA, testing for taxon, age, sex, and interaction effects. We compared all measurements and metric tail characters of the two taxa by age/sex class with box plots, and we compared means with one-way ANOVA. For characters that had different means, we determined if differences were diagnosable at levels between $75 \%$ and $99 \%$ in $1 \%$ increments, following the method described in Patten and Unitt (2002). We then used DFA to find the linear combination of variables that best separated the two taxa. We examined correlation coefficients of each pairwise combination of variables to ensure no highly correlated $(r>0.70)$ pairs were included in the DFA (Green 1979, Magnusson 1983). In the DFA we used the squared Mahalanobis distances as our measure of group differences, and we used the jackknifed classification procedure on the original cases to assign specimens to taxon. We also calculated the mean and SE of posterior classification probabilities for each case to assess relative confidence in the classifications, and we evaluated the diagnosability of canonical scores as described for measurement variables. We tested the significance of discriminant functions with Wilks' $\lambda$ transformed to an approximate $F$ distribution. ANOVA and DFA were run in SYSTAT 13 (SYSTAT 2009). We calculated the sexual dimorphism index (SDI) for each character and the mean SDI over all characters by the method described in Snyder and Wiley (1976). We calculated the SDI separately for adults and juveniles of both $B$. n. nitidus and $B . n$. plagiatus.

We compared vocalization metrics of the two taxa with box plots, and we compared means by one-way ANOVA. For characters that had different means, we determined if differences were diagnosable, and we used DFA to find the linear combination of vocalization variables that best separated the two taxa, following the approach described above for measurement data.

We considered $\alpha=0.05$ as the critical value for significance in statistical tests. Values in text and tables are means $\pm \mathrm{SE}$.

\section{RESULTS}

\section{PLUMAGES}

Plumage regions of the two taxa differed consistently in both juveniles and adults. All museum specimens from locations north of the distribution gap in Costa Rica had plumage characteristics of $B . n$. plagiatus, whereas all specimens from locations south of the gap had plumage characteristics of $B . n$. nitidus (Table 1, Figs. 1, 2). Intrataxon plumage variation was minimal relative to intertaxon differences, and almost all individuals of each taxon were as depicted in Figure 1. From the distributions of specimens, the width of the range gap appears to be no more than $\sim 50 \mathrm{~km}$ (Fig. 2).

TABLE 1. Plumage differences between B. n. nitidus and B. n. plagiatus based on examination of 405 museum specimens (Appendix A). Plumage regions follow Blake (1956). The differences are shown in Fig. 1, and numerals and letters in parentheses in the table refer to illustrations in that figure.

\begin{tabular}{|c|c|c|}
\hline \multirow[b]{2}{*}{ Region } & \multicolumn{2}{|c|}{ Taxon } \\
\hline & B. n. nitidus (1) & B.n.plagiatus (2) \\
\hline \multicolumn{3}{|l|}{ Adult } \\
\hline $\begin{array}{l}\text { Crown, nape, } \\
\text { humeral, back }(\mathrm{b}, \mathrm{e})\end{array}$ & $\begin{array}{c}\text { Gray, narrow dark } \\
\text { barring }\end{array}$ & $\begin{array}{l}\text { Dark gray, } \\
\text { no barring }\end{array}$ \\
\hline $\begin{array}{l}\text { Upper tail } \\
\text { coverts (b) }\end{array}$ & Gray, white tips & White \\
\hline \multicolumn{3}{|l|}{ Juvenile } \\
\hline Crown (f) & Buffy, dark streaks & Dark brown \\
\hline Auricular (f) & Buffy & White \\
\hline Malar stripe (f) & Absent & $\begin{array}{l}\text { Dark, } \\
\text { pronounced }\end{array}$ \\
\hline Breast, belly $(\mathrm{c}, \mathrm{f})$ & Buffy, dark blobs & $\begin{array}{l}\text { White, narrow } \\
\text { dark streaks }\end{array}$ \\
\hline Crural $(\mathrm{c}, \mathrm{f})$ & Buffy, unmarked & $\begin{array}{l}\text { White, narrow } \\
\text { dark bands }\end{array}$ \\
\hline $\begin{array}{l}\text { Primaries, upper } \\
\text { surface (d) }\end{array}$ & $\begin{array}{l}\text { Large buffy } \\
\text { light patch }\end{array}$ & $\begin{array}{l}\text { Dark brown, } \\
\text { no patch }\end{array}$ \\
\hline $\begin{array}{l}\text { Rectrices, upper } \\
\text { surface (d) }\end{array}$ & $\begin{array}{l}\text { Base whitish, } \\
\text { wide bands }\end{array}$ & $\begin{array}{l}\text { Base brown, } \\
\text { narrow bands }\end{array}$ \\
\hline Upper tail coverts (d) & Buffy & $\begin{array}{l}\text { White, dark shaft } \\
\text { streaks }\end{array}$ \\
\hline
\end{tabular}




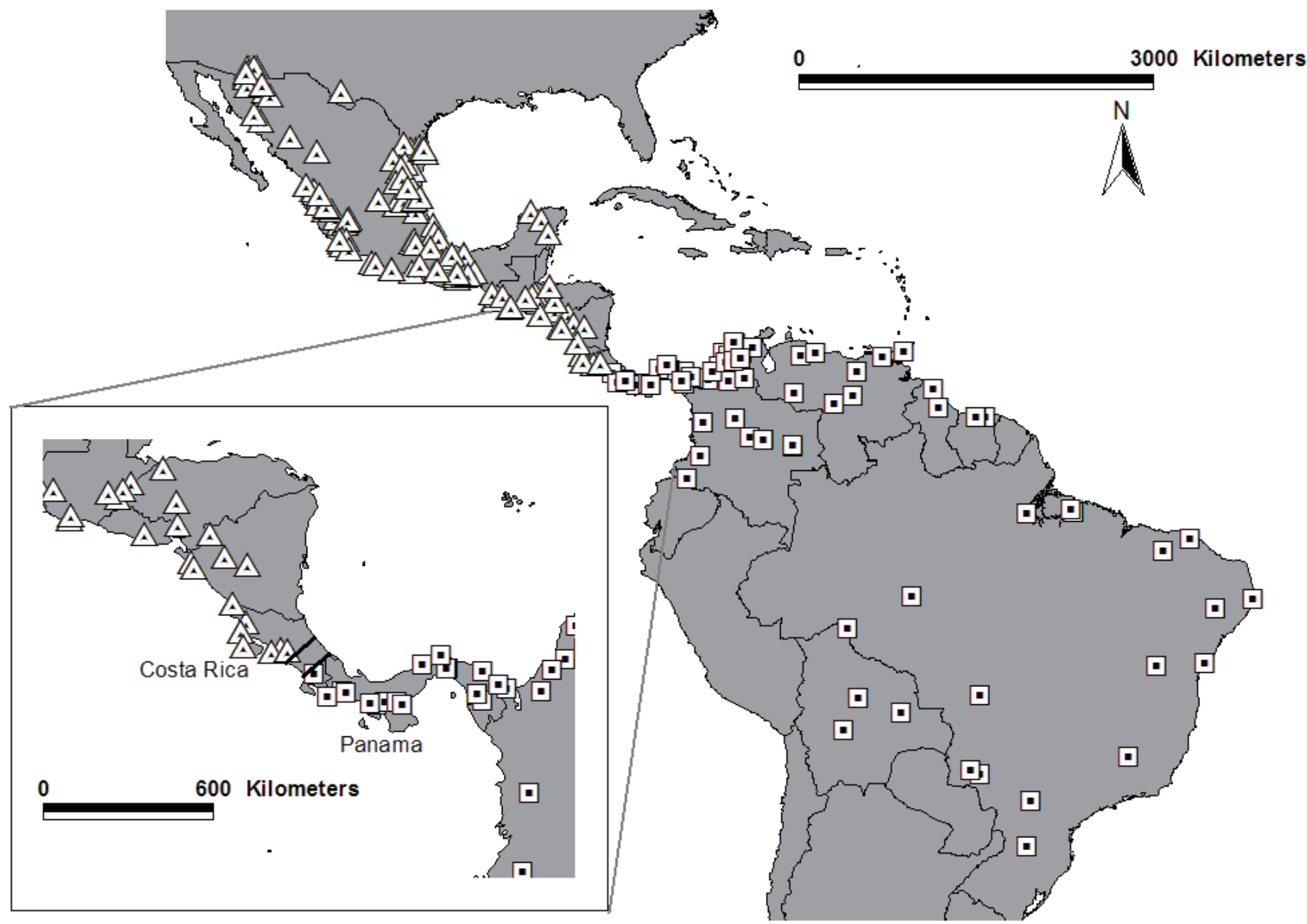

FIGURE 2. Classification of specimens of B. nitidus to B. n. nitidus or plagiatus on the basis of plumage characteristics in Table 1. Specimens represented by a square had characters of $B . n$. nitidus; specimens represented by a triangle had characters of $B$. n. plagiatus (see Table 1, Fig. 1). The inset shows the distribution and classification of specimens in the vicinity of the range gap in Costa Rica; see text for details.

The tail patterns of $B . n$. nitidus and $B . n$. plagiatus also differed, but in most characters, considered singly, the difference did not reach the threshold of diagnosability. Adults of both sexes of $B . n$. plagiatus had wider white second tail bands, had more rectrices with a second white tail band, and more often had evidence of a third white band than did adults of $B . n$. nitidus (Fig. 3). Adults' tail-band characters overlapped somewhat; therefore, the two taxa did not meet the criterion of diagnosability by these characters alone. Juveniles of both sexes of $B . n$. plagiatus had more dark bands in the tail than did juveniles of $B$. n. nitidus; the number of dark tail bands met the criterion of diagnosability at the $75 \%$ level for males and at the $80 \%$ level for females.

\section{MORPHOLOGY}

The two taxa overlapped somewhat in all measurements, so they did not meet the criterion of diagnosability by any single one of these characters. However, the wing and tail of $B . n$. plagiatus were significantly longer than those of B. n. nitidus, and some characters associated with prey capture and handling differed for some but not all classes (Figs. 4, 5). Buteo n. plagiatus had a longer primary projection $(59.5 \pm 1.8 \mathrm{~mm}$, $n=37)$ than did $B . n$. nitidus $(44.0 \pm 1.9 \mathrm{~mm}, n=27)$ (threeway ANOVA; taxon-effect $F=33.640, \mathrm{df}=1,50, P<0.001$; $P>0.05$ for age/sex-class effects and interaction effects), but the differences did not reach the criterion of diagnosability at any level. The mean SDI was 1.7 to 2.0 times larger for $B . n$. plagiatus than for $B$. $n$. nitidus (Table 2). The difference was especially evident for measurements of wing length, tarsus width, and maxilla depth.

Culmen length and maxilla depth were strongly correlated with hind-claw length; we retained the hind-claw measurement for DFA because bill measurements were not available for a number of specimens on which the maxilla had been damaged. DFA resulted in correct classification of $100 \%$ of juveniles, $98 \%$ of adult males, and $88 \%$ of adult females. Mean discriminate 
Female
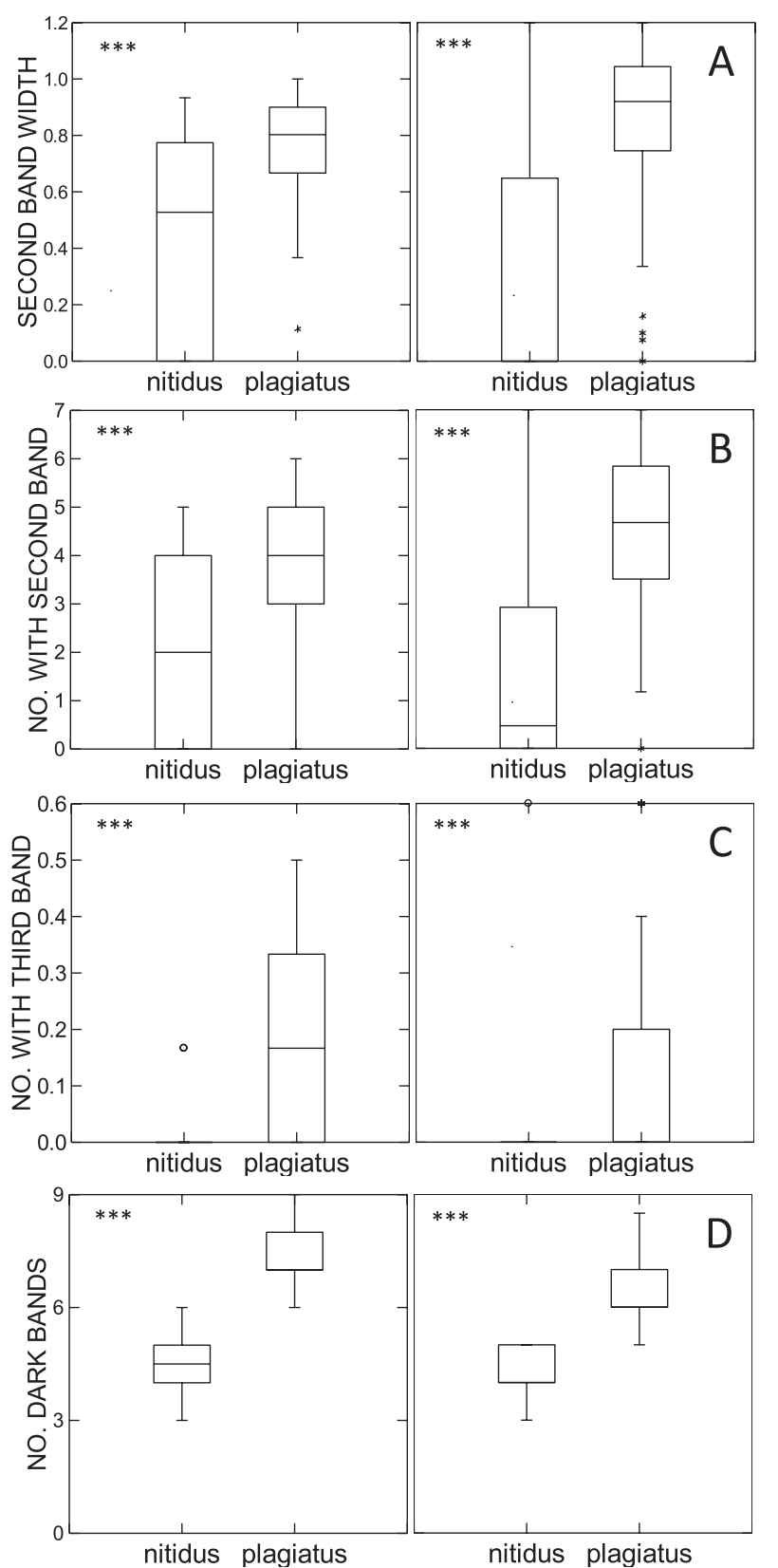

FIGURE 3. Box plots summarizing tail characters of $B . n$. nitidus and $B . n$. plagiatus. The horizontal line in the boxes is the median, boxes cover the median $50 \%$ of values (interquartile range), the whiskers extend outward from box hinges 1.5 times the interquartile range, and asterisks beyond whiskers are outside values. Means for each character were compared with one-way ANOVA, and asterisks or notation in the upper left corner of each graph depict results (nd, no difference; $\left.{ }^{*} 0.10 \geq P \geq 0.05 ; * * * P<0.01\right)$. A, $\mathrm{B}$, and $\mathrm{C}$ are adult characters, A the proportional width of the second (proximal) white tail band relative to the width of right central rectrix, $B$ the number of rectrices on the right side of the tail with an unbroken second white band, and $\mathrm{C}$ the number of rectrices on the right side of the ail with an unbroken third white band. Character D, the number of dark bands on the right side of the tail, is a juvenile character. scores of all groups differed (Table 3). Posterior classification probabilities exceeded $95 \%$ for $95 \%$ of adult males, $66 \%$ of adult females, $96 \%$ of juvenile males, and $92 \%$ of juvenile females. Misclassified specimens were primarily from southern Central America and northern South America.

\section{VOCALIZATIONS}

Alarm calls of B. n. nitidus and B. n. plagiatus were aurally and visually different (Fig. 6). Means of all measured characteristics of the alarm notes of $B . n$. nitidus and $B . n$. plagiatus differed ( $P<0.04$ for all comparisons). Box plots showed complete separation of B. n. nitidus and B. n. plagiatus on the variables time and pitch drop, with the exception of three recordings of $B$. $n$. nitidus from Venezuela that had times more typical of B.n. plagiatus (Fig. 7). Two of these recordings were of juveniles that were or may have been dependent on their parents (ML58986, ML112269), and the third was of a bird obscured by vegetation and not observed, but the call was described as atypically protracted (ML58990). From similarities between ML58990 and calls of known juveniles of $B$. n. niti$d u s$, we suspect this call was also from a juvenile $B . n$. nitidus. Even with the apparent complication of age-related variation in call structure, alarm calls of B. n. nitidus and B. n. plagiatus were diagnostically different at the $99 \%$ level for pitch drop, and at the $75 \%$ level for time. Time and interquartile-range duration were highly correlated $(r=0.778)$, so we retained the more direct measure, time, for DFA. Mean discriminate scores for B. n. nitidus and B. n. plagiatus differed, and $100 \%$ of individuals were classified to the correct taxon with high certainty (Table 4).

\section{DISCUSSION}

We found that allopatric $B . n$. nitidus and B. n. plagiatus differ diagnosably at very high probability levels in all age and sex classes across a range of plumage, measurement, and vocalization characters. The two taxa were entirely separable by plumage, even where their ranges approach one another in Costa Rica. DFA using measurements of body and tail-pattern characters resulted in correct classification of $\geq 98 \%$ of juveniles and adult males and $88 \%$ of adult females, and DFA using alarm-call measurements resulted in correct classification of $100 \%$ of the vocalizations.

Riesing et al. (2003) found the mtDNA distance between B. n. nitidus and B. n. plagiatus was $9 \%$, the same distance as between $B$. n. nitidus and B. jamaicensis costaricensis. In interpreting this finding, Riesing et al. (2003:340) stated "Thus, the earlier proposed species status of plagiatus ... is supported by our data." There are two reasons to be cautious about interpreting the findings of Riesing et al. (2003), however. First, their sample was very small, $n=2$ for $B$. $n$. nitidus and $n=1$ for $B$. $n$. plagiatus. Second, the samples of $B . n$. nitidus (Ecuador and Brazil) and that of B. n. plagiatus (Costa Rica) came from localities far apart, leaving uncertainty whether 

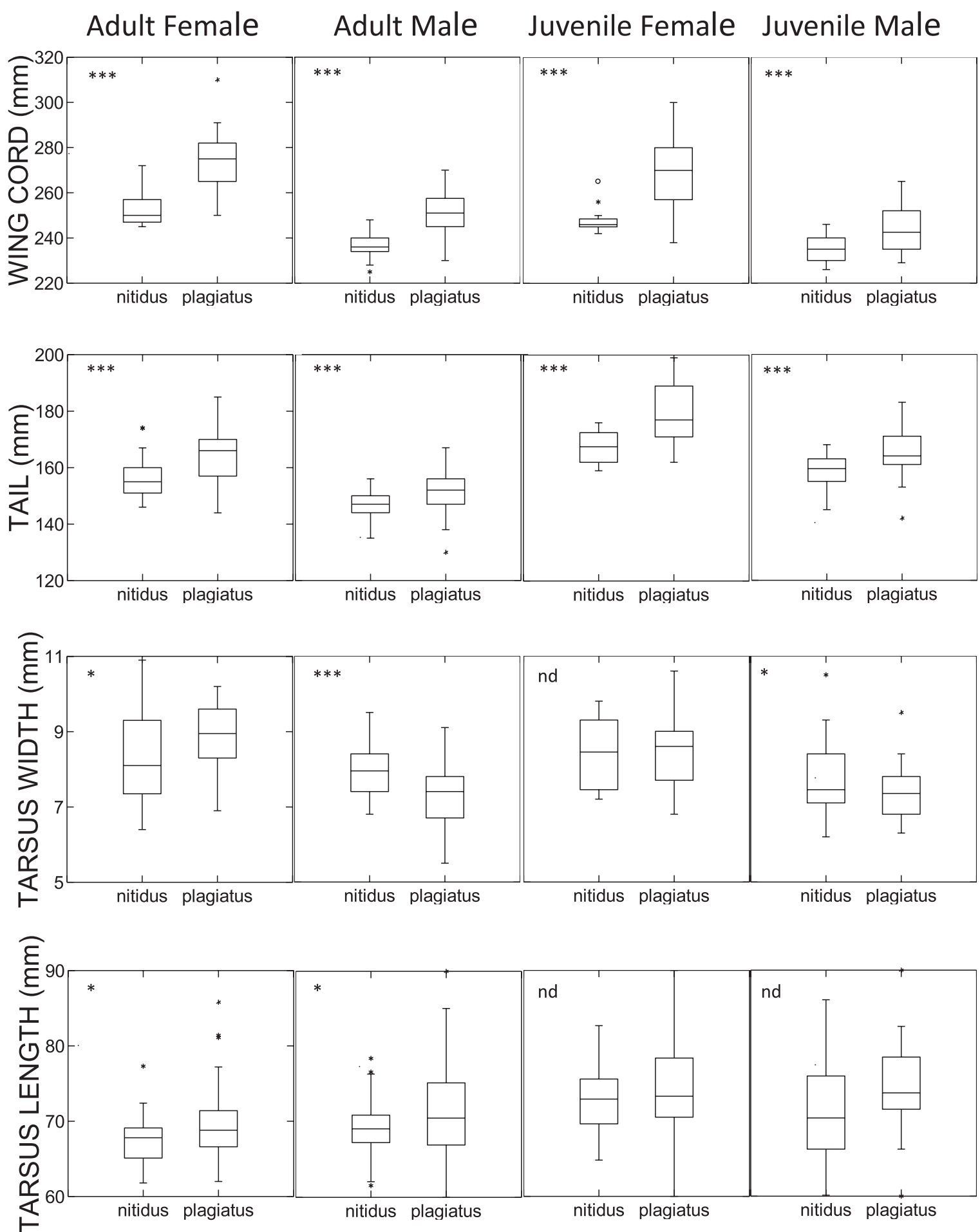

FIGURE 4. Box plots summarizing measurements of B. n. nitidus and B. n. plagiatus: wing, tail, and leg characters by taxon. The horizontal line in boxes is the median, boxes cover the median $50 \%$ of values (interquartile range), the whiskers extend outward from box hinges 1.5 times the interquartile range, and asterisks beyond whiskers are outside values. Means for each character were compared with one-way ANOVA, and asterisks or notation in the upper left corner of each graph depict results (nd, no difference; $* 0.10 \geq P \geq 0.05$; $* * * P<0.01)$. 

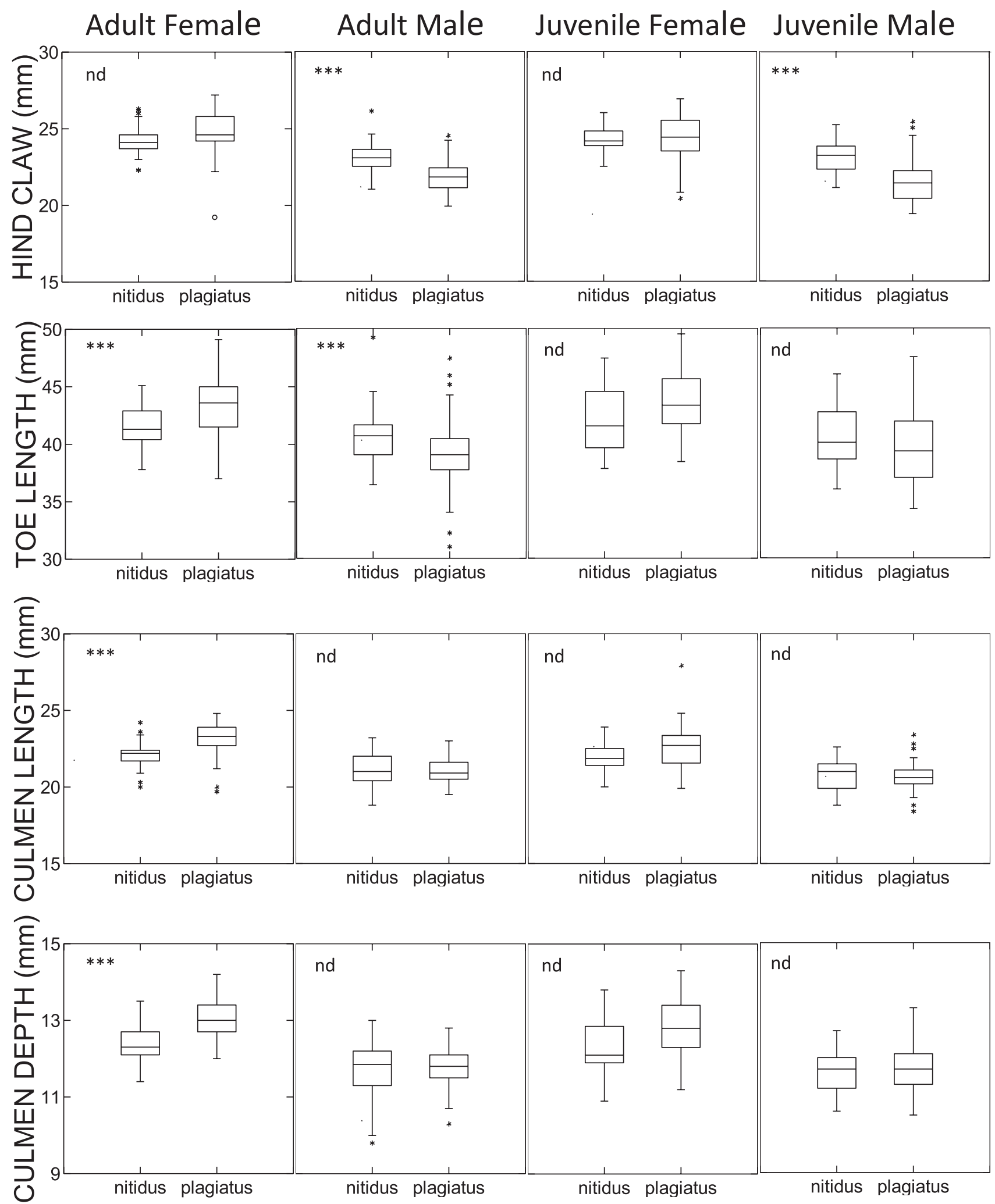

FIGURE 5. Box plots summarizing measurements of prey-handling characters of $B$. n. nitidus and B. n. plagiatus. The horizontal line in boxes is the median, boxes cover the median $50 \%$ of values (interquartile range), the whiskers extend outward from box hinges 1.5 times the interquartile range, and asterisks beyond whiskers are outside values. Means for each character were compared with one-way ANOVA, and asterisks or notation in the upper left corner of each graph depict results (nd, no difference; $* 0.10 \geq P \geq 0.05 ; * * * P<0.01$ ). 
TABLE 2. Sexual size dimorphism index for B. n. nitidus and B. n. plagiatus, calculated from means of measurements presented in Figs. 4 and 5 according to the method described in Snyder and Wiley (1976).

\begin{tabular}{|c|c|c|c|c|c|c|c|c|c|}
\hline & Wing & Tail & $\begin{array}{l}\text { Tarsus } \\
\text { width }\end{array}$ & $\begin{array}{l}\text { Tarsus } \\
\text { length }\end{array}$ & $\begin{array}{l}\text { Hind } \\
\text { claw }\end{array}$ & Toe & $\begin{array}{l}\text { Culmen } \\
\text { length }\end{array}$ & $\begin{array}{l}\text { Maxilla } \\
\text { depth }\end{array}$ & Mean \\
\hline \multicolumn{10}{|l|}{ Adult } \\
\hline B.n. nitidus & 0.04 & 0.04 & 0.04 & 0.02 & 0.03 & 0.02 & 0.03 & 0.04 & 0.03 \\
\hline B.n.plagiatus & 0.05 & 0.05 & 0.13 & 0.02 & 0.08 & 0.07 & 0.06 & 0.07 & 0.06 \\
\hline \multicolumn{10}{|l|}{ Juvenile } \\
\hline B. n. nitidus & 0.06 & 0.06 & 0.08 & 0.02 & 0.05 & 0.03 & 0.06 & 0.06 & 0.05 \\
\hline B.n.plagiatus & 0.09 & 0.08 & 0.14 & 0.02 & 0.12 & 0.10 & 0.09 & 0.08 & 0.09 \\
\hline
\end{tabular}

the geographic pattern of genetic differentiation corresponds with the pattern of morphological and vocal differentiation we observed. However, the sheer magnitude of the genetic difference is noteworthy given that many pairs of good species, especially those that have recently evolved, are indistinguishable in their mtDNA (Funk and Omland 2003). We think that the best interpretation of the available information is that B. n. nitidus and B. n. plagiatus do differ genetically at a level comparable to that of other pairs of full species in the genus Buteo and that the mtDNA shift occurs across a zone that includes the gap in distribution where the plumage, morphology, and alarm note change.

In addition to morphological, vocal, and genetic differences, we found that the sexual dimorphism (as well as the size of some characters related to prey capture and handling) of $B . n$. nitidus and B. n. plagiatus differ. Snyder and Wiley (1976) demonstrated a strong relationship between the degree of sexual size dimorphism in raptors and aspects of their diet. Therefore, the differences in dimorphism suggest the taxa may also differ in the types and relative sizes of prey the sexes capture.

TABLE 3. Results of discriminant function analysis of morphological measurements of B.n.nitidus and B. n. plagiatus. Values in table are the canonical discriminant function coefficients and constants. Classification results, Wilks' $\lambda$ test of equality of group centroids, mean canonical scores for each taxon, mean (SE) posterior classification probabilities for all cases, and diagnosability levels for canonical scores are also presented.

\begin{tabular}{|c|c|c|c|c|}
\hline Variable & Adult male & Adult female & Juvenile male & Juvenile female \\
\hline Constant & 17.12 & -22.63 & -3.07 & -8.7 \\
\hline Wing & 0.10 & 0.08 & 0.05 & 0.033 \\
\hline Tail & 0.00 & -0.01 & 0.01 & -0.03 \\
\hline Tarsus width & -0.64 & 0.15 & -0.26 & -0.151 \\
\hline $\ln (\text { tarsus length })^{\mathrm{a}}$ & 4.56 & 1.64 & 5.49 & -6.056 \\
\hline $\ln (\text { hind claw })^{\mathrm{a}}$ & -15.36 & -6.08 & -12.03 & -0.474 \\
\hline $\ln (\text { toe })^{\mathrm{a}}$ & -2.27 & 3.74 & -1.67 & 4.499 \\
\hline sqr(rectrices with second band $)^{\mathrm{a}}$ & 0.83 & 0.09 & - & - \\
\hline $\operatorname{sqr}(\text { rectrices with third band })^{a}$ & 0.37 & 0.63 & - & - \\
\hline asn (second-band width) $)^{\mathrm{a}}$ & 0.25 & 1.25 & - & - \\
\hline sqr(no. dark tail bands) ${ }^{\mathrm{a}}$ & - & - & 5.04 & 6.7 \\
\hline Correct classification & $98 \%$ & $88 \%$ & $100 \%$ & $100 \%$ \\
\hline Wilks' $\lambda(F)$ & 40.33 & 11.78 & 28.92 & 17.29 \\
\hline df & 9,114 & 9,78 & 7,48 & 7,29 \\
\hline$P$ & $<0.001$ & $<0.001$ & $<0.001$ & $<0.001$ \\
\hline Canonical score $B . n$. nitidus group mean & -2.71 & -1.53 & -2.81 & -2.87 \\
\hline Canonical score $B . n$. plagiatus group mean & 1.15 & 0.871 & 1.45 & 1.38 \\
\hline Mean (SE) posterior probability $B . n$. nitidus & $0.95(0.01)$ & $0.85(0.08)$ & $1.00(0)$ & $0.97(0.08)$ \\
\hline $\begin{array}{l}\text { Mean (SE) posterior probability } \\
\text { B.n. plagiatus }\end{array}$ & $0.97(0.03)$ & $0.82(0.07)$ & $1.00(0)$ & $0.98(0.04)$ \\
\hline Diagnosability of mean canonical scores ${ }^{b}$ & $90 \%$ & $<75 \%$ & $95 \%$ & $92 \%$ \\
\hline
\end{tabular}

${ }^{a}$ In precedes log-transformed variables, sqr precedes square-root-transformed variables, and asn precedes angular(arcsine-) transformed variables.

bercentage of the population of both taxa that lies outside $99 \%$ of the range of the other taxa, as described in Patten and Unitt (2002). 


\section{B. n. plagiatus}
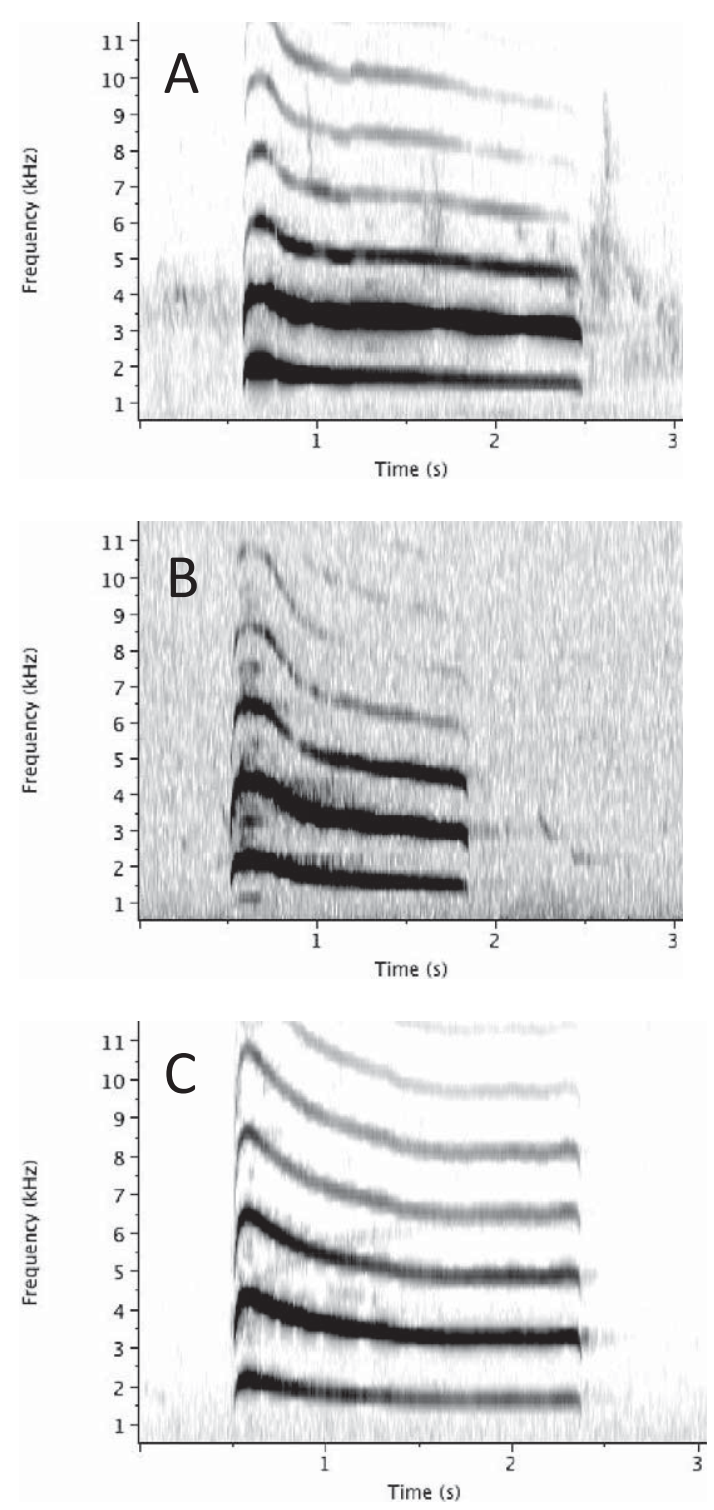

\section{B. n. nitidus}
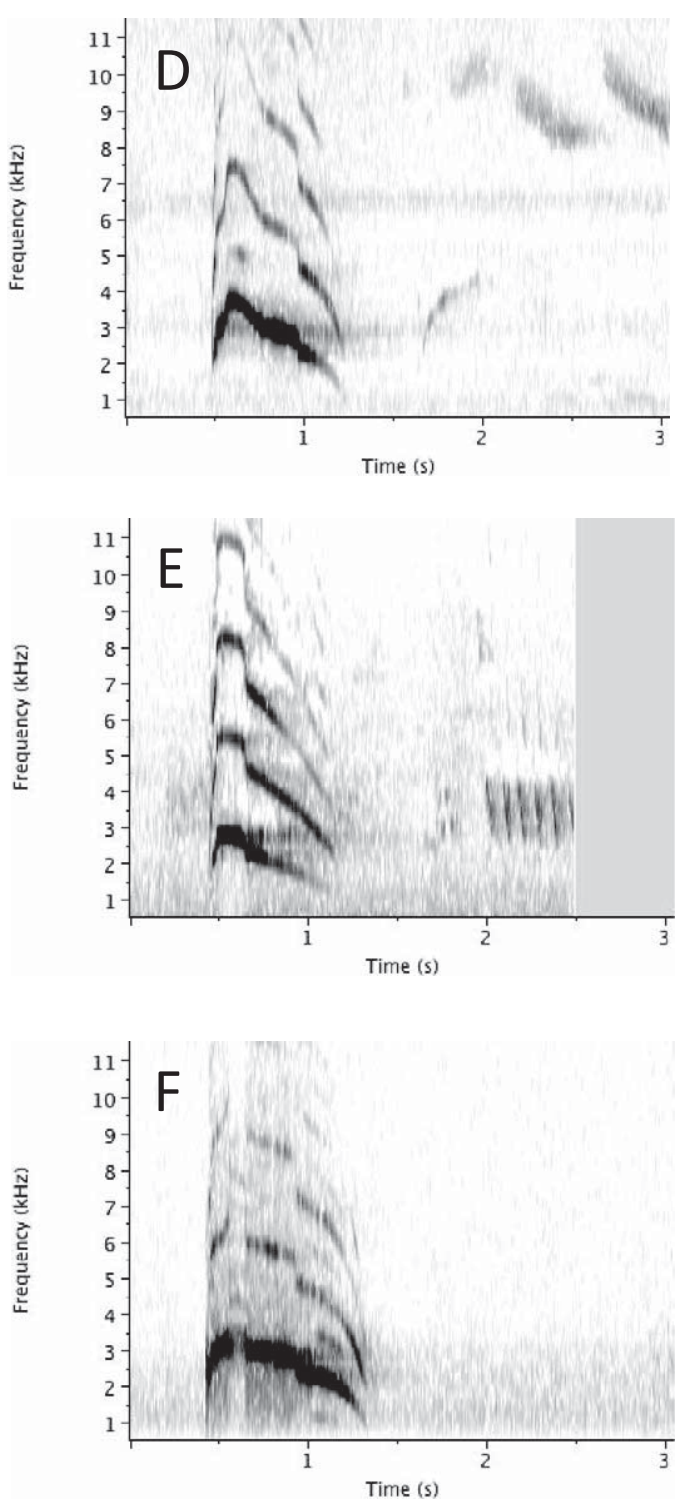

FIGURE 6. Example alarm calls of B. n. nitidus and B. n. plagiatus. Calls from B. n. plagiatus were longer, had more densely packed harmonics, most of the sound energy was concentrated in the second harmonic, and showed a smooth variation of the frequency along the note. Calls from $B . n$. nitidus were typically shorter, had more sparse harmonics, had sound energy concentrated in the first harmonic, and all showed a diagnostic sudden drop in pitch near the middle of the note. Call A was recorded in Arizona (ML 109002; see Appendix B), call B is from Colima, Mexico (ML 89721), call C is from El Rama, Nicaragua (XC 10888), call D is from Bolívar, Venezuela (ML 58987), call E is from Guayas, Ecuador (XC 4), and call F is from Alto Paraguay, Paraguay (XC 55595).

Slud (1964) noted that in Costa Rica B. n. nitidus and B. n. plagiatus occur almost exclusively in the tropical dry forest. The tropical dry forest is replaced immediately south of the Gulf of Nicoya on the Pacific slope by tropical moist forest, which continues southward into northern Panama (Slud 1964, Ridgely 1976, Janzen 1983).

It is this band of moist forest that currently appears to separate the ranges of $B . n$. nitidus and B. n. plagiatus, and by a narrow distance of about $50 \mathrm{~km}$. The moist forest in Central America has variously expanded and contracted in association with Pleistocene glaciation (Haffer 1974, van der Hammen 1974, Marshall et al. 1982, Rich and Rich 1983). Presumably, these Pleistocene events contributed to the isolation and differentiation of $B$. n. nitidus and $B . n$. plagiatus, as is the case with many other avian taxa (Avise and Walker 1998, Klicka and Zink 1999, Johnson and Cicero 2004). However, 

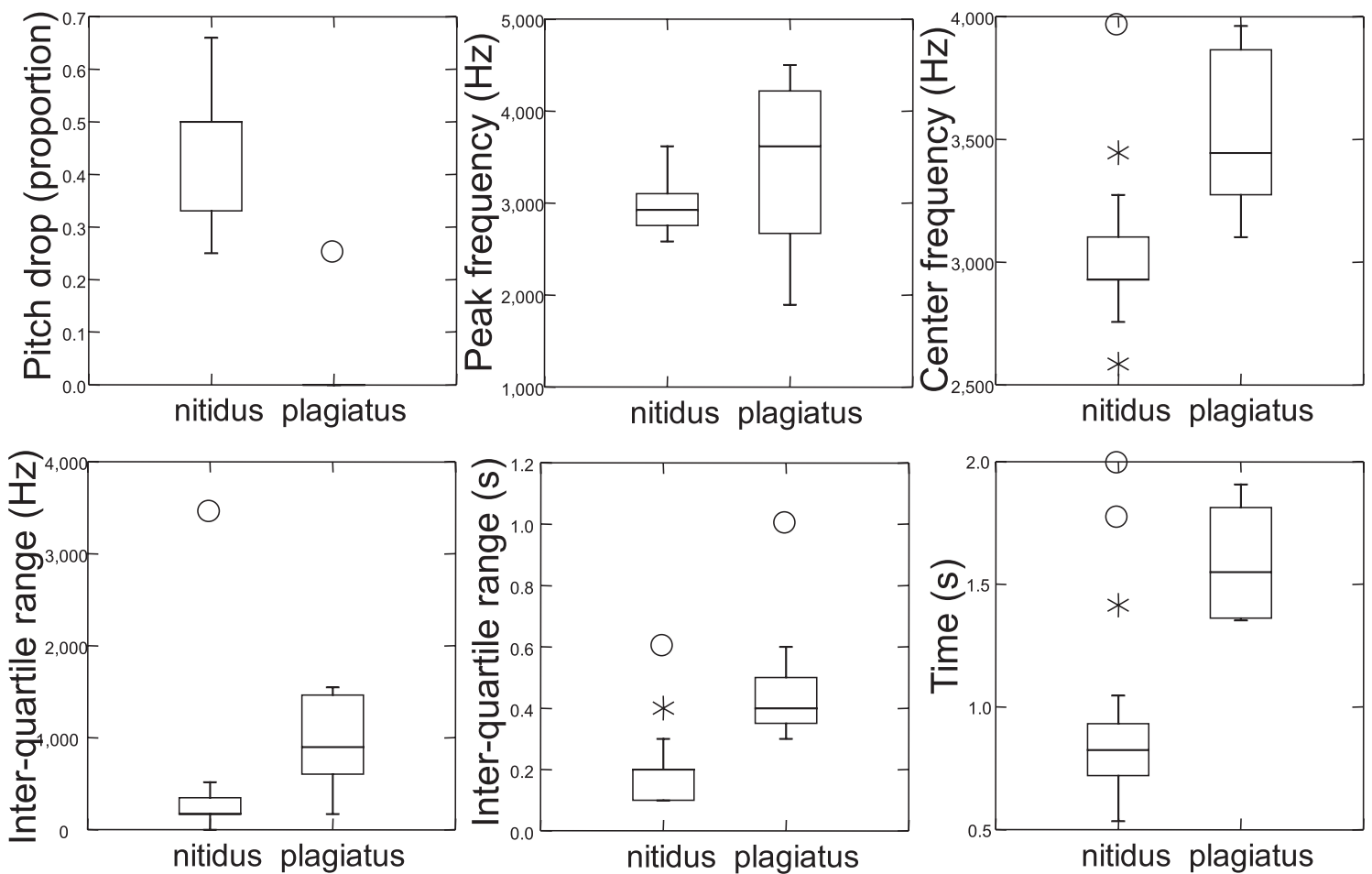

FIGURE 7. Box plots summarizing metrics of alarm notes of B. n. nitidus and B. n. plagiatus. The horizontal line in boxes is the median, boxes cover the median $50 \%$ of values (interquartile range), the whiskers extend outward from box hinges 1.5 times the interquartile range, asterisks denote outside values, and circles denote far outside values. All means were found to be different in one-way ANOVAs ( $P \leq 0.035$ in all cases)

TABLE 4. Results of discriminant function analysis for alarm calls of $B$. n. nitidus and B. n. plagiatus. Values in table are the canonical discriminant function coefficients and constants. Classification results, Wilks' $\lambda$ test of equality of group centroids, mean canonical scores for each taxon, mean (SE) posterior classification probabilities for all cases, and diagnosability levels for canonical scores are also presented.

\begin{tabular}{|c|c|}
\hline Variable & Value \\
\hline Constant & -0.905 \\
\hline $\operatorname{asn}(\text { pitch drop })^{\mathrm{a}}$ & -7.584 \\
\hline Peak frequency & 0 \\
\hline Center frequency & 0.001 \\
\hline Interquartile-range bandwidth & 0 \\
\hline Time & 0.957 \\
\hline Correct classification & $100 \%$ \\
\hline Wilks' $\lambda(F)$ & 40.01 \\
\hline df & 5,27 \\
\hline$P$ & $<0.001$ \\
\hline Canonical score nitidus group mean & -1.49 \\
\hline Canonical score plagiatus group mean & 4.66 \\
\hline Mean (SE) posterior probability nitidus & $1.00(0)$ \\
\hline Mean (SE) posterior probability plagiatus & $1.00(0)$ \\
\hline Diagnosabilty of mean canonical scores b & $99 \%$ \\
\hline
\end{tabular}

a asn precedes angular- (arcsine-) transformed variables. bercentage of the population of both taxa that lies outside $99 \%$ of the range of the other taxa, as described in Patten and Unitt (2002). if the mtDNA divergence reported by Riesing et al. (2003) is correct, and a rate of molecular divergence of $2 \%$ per million years is assumed (Johnson and Cicero 2004), the initial separation of $B$. n. nitidus and B. n. plagiatus must have occurred in the Pliocene Epoch, approximately 4.5 million years ago. This timing is consistent with a period of divergence in a number of other neotropical buteonine taxa coincident with the closure of the Panamanian isthmus, 15.5-2.8 million years ago (Amaral et al. 2009). Thus the divergence of $B$. $n$. nitidus and $B$. $n$. plagiatus appears to fit the pattern evident in a number of $B u$ teo species, in which initial separation and divergence began in the Pliocene but were affected by, and in this case possibly maintained by, Pleistocene events (Avise and Walker 1998, Klicka and Zink 1999, Amaral et al. 2009). Although recent clearing of the moist forest for agriculture has created patches of habitat seemingly suitable for the Gray Hawk in central and southern Costa Rica (Slud 1964), B. n. nitidus and B. n. plagiatus appear to remain geographically isolated, though the proximity of their ranges suggests some contact, if it has not already occurred, is likely in the future.

The British Ornithologists Union, which uses elements of the biological and phylogenetic species concepts in evaluating avian taxonomic rank, has adopted the following criteria for assigning species rank to allopatric taxa: "they are fully diagnosable in each of several discrete or continuously varying characters related to different functional contexts, e.g., structural 
features (often related to foraging strategy), plumage colors, vocalizations (both often related to mate recognition) or DNA sequences, and the sum of the character differences corresponds to or exceeds the level of divergence seen in related species that coexist in sympatry" (Helbig et al. 2002:53). Under these criteria, we believe species rank for $B$. n. nitidus and $B$. n. plagiatus is fully supported because (1) all age and sex classes are completely distinct on the basis of several discrete plumage features; (2) three of four age and sex classes are diagnosably distinct at the $\geq 90 \%$ probability level on the basis of DFA-derived canonical scores of group means, (3) the two taxa have diagnosably different alarm calls at the $99 \%$ probability level, on the basis of DFA-derived canonical scores of group means, and (4) there is evidence the taxa differ in mtDNA at a level comparable to that seen between other full species in the genus. The latter point may be of questionable significance given that the relationship between genotypic and phenotypic differentiation in birds in general (Winker 2009 ) and in the genus Buteo specifically (Kruckenhauser et al. 2004) is unclear. However, the fact that B. n. nitidus and $B$. n. plagiatus appear to differ in both genotype and phenotype, and that the phenotypic differences are consistent and include a broad range of characters, supports a conclusion that the taxa warrant treatment as different species. This conclusion is further supported by the fact that several other species of Buteo currently recognized diverge phenotypically at levels similar to what we found for $B$. n. nitidus and $B$. n. plagiatus. From our collective field and museum work with most species of Buteo, we would include in this group B. brachyurus and B. albigula, B. lineatus and B. ridgwayi, and B. albicaudatus and B. polyosoma (although Amaral et al. 2009 provided evidence the latter species pair may be better placed in the genus Geranoaetus). Buteo jamaicensis and B. ventralis provide another example, though the lack of genetic differentiation between these taxa calls into question their status as species and suggests a much more recent split than for $B$. n. nitidus and B. n. plagiatus (Riesing et al. 2003).

The American Ornithologists' Union Committee on Classification and Nomenclature did not consider the findings of Riesing et al. (2003) compelling with regard to the species status of $B . n$. nitidus and B. n. plagiatus in the absence of additional supporting data (Banks et al. 2006). In this paper we present that supporting data for plumage, morphology, and vocalizations. Collectively, all lines of evidence strongly suggest that the current treatment of $B . n$. nitidus and $B . n$. plagiatus as conspecific does not accurately reflect the extent of differentiation between the two taxa. We recommend they be considered two species as described below:

Buteo nitidus (Latham 1790). We propose use of the name Gray-lined Hawk for this species, previously applied to it by Meyer de Schauensee (1966). The range of this species extends from southwestern Costa Rica south to eastern Peru, central Bolivia, southern Paraguay, northern Argentina, and southern Brazil.
Buteo plagiatus (Schlegel 1862). We propose retention of the common name Gray Hawk for this species, following the convention of other authors who have proposed species status for B. nitidus and B. plagiatus (Sibley and Monroe 1990). The range of this species is from southeastern Arizona, southern New Mexico, and southern and western Texas south to northwestern Costa Rica.

\section{ACKNOWLEDGMENTS}

This work is based in part on BAM's M.Sc. thesis, and he acknowledges the support of the Biology Department at George Mason University, and particularly the guidance of his committee chair D. W. Johnston and committee member R. C. Banks. BAM's work was supported by grants from the U.S. Fish and Wildlife Service, Southwest Region, and from the Frank M. Chapman Memorial Fund, American Museum of Natural History. Field and museum work by SHS was partially financed by The Peregrine Fund, Princeton University Press, and Ben Olewine III. We all gratefully acknowledge the assistance and access to museum material provided by all the institutions visited, and we recognize this material is available only because of the dedication of the many ornithologists and naturalists who preceded us. We thank T. Bishop and J. I. Areta for their assistance in providing digital call recordings from the Macaulay Library at Cornell University, and we thank all those who contributed their call recordings to these institutions. L. Sandoval graciously allowed us to use his call recording from Costa Rica. We thank Princeton University Press for permission to use the illustrations of the Gray Hawk and Gray-lined Hawk in Figure 1 and J. Schmitt, the artist, who agreed to this permission. The illustrations will be in a field guide to the raptors of Mexico and Central America authored by WSC and J. Schmitt and published by Princeton University Press. J. I. Areta, B. Howe, J. Morgart, M. Patten, S. Chambers, and three anonymous reviewers made helpful comments on earlier versions of the manuscript. The findings and conclusions in this article are those of the author(s) and do not necessarily represent the views of the U.S. Fish and Wildlife Service.

\section{LITERATURE CITED}

Amaral, F. R., F. H. Sheldon, A. Gamauf, E. Haring, M. Riesing, L. F. Silveira, AND A. Wajntal. 2009. Patterns and processes of diversification in a widespread and ecologically diverse avian group, the buteonine hawks (Aves, Accipitridae). Molecular Phylogenetics and Evolution 53:703-715.

AmERICAN ORNITHOLOGISTS' UnION. 1983. Checklist of North American birds, 6th ed. American Ornithologists' Union, Washington, D.C.

American Ornithologists' Union. [Online]. 2008. Check-list of North American Birds. American Ornithologists' Union, Washington, DC. <http://www.aou.org/checklist/index.php3> (24 February 2010).

Avise, J. C., AND WALKeR, D. 1998. Pleistocene phylogeographic effects on avian populations and the speciation process. Proceedings of the Royal Society of London B 265:457-463.

BAIRD, S. F., T. M. BREWER, AND R. RidgWAY. 1874. A history of North American birds, vol. 3. Little Brown, Boston.

Banks R. C., C. Cicero, J. L. Dunn, A. W. Kratter, P. C. Rasmussen, J. V. Remsen JR., J. D. Rising, And D. Stotz. 2006. Forty-seventh supplement to the American Ornithologists' Union Check-list of North American birds. Auk 123:926-936.

BibLEs, B. D., R. L. GLinSKI, AND R. R. JohnSON. 2002. Gray Hawk (Asturina nitida), no. 652. In A. Poole and F. Gill [EDS.], The birds of North America. Birds of North America, Inc., Philadelphia. 
BierregaArd, R. O. 1994. Grey Hawk, p. 176. In J. del Hoyo, A. Elliot, and J. Sargatal [EDS.], Handbook of the birds of the world, vol. 2. Lynx Edicions, Barcelona.

BLAKE, C. H. 1956. The topography of a bird. Bird-Banding 27:22-31.

BlAKE, E. R. 1977. Manual of neotropical birds. University of Chicago Press, Chicago.

Ferguson-LeEs, J., AND D. A. Christie. 2001. Raptors of the world. Christopher Helm, London.

FriedmanN, H. 1950. Birds of North and Middle America, part 11. U.S. National Museum Bulletin 50.

FunK, D. J., AND K. E. OMLAND. 2003. Species-level paraphyly and polyphyly: frequency, causes, and consequences, with insight from animal mitochondrial DNA. Annual Review of Ecology, Evolution, and Systematics 34:397-423.

Green, R. H. 1979. Sampling design and statistical methods for environmental biologists. Wiley, New York.

HAfFer, J. 1974. Avian speciation in tropical South America. Publications of the Nuttall Ornithological Club.14.

Helbig, A. J., A. G. Knox, D. T. Parkin, G. Sangster, and M. Collinson. 2002. Guidelines for assigning species rank. Ibis 144:518-525.

JANZEN, D. H. (ED.) 1983. Costa Rican natural history. University of Chicago Press, Chicago.

JoHnSON, N. K., AND C. CICERO. 2004. New mitochondrial DNA data affirm the importance of Pleistocene speciation in North American birds. Evolution 58:1122-1130.

Johnson, N. K., AND H. J. PeETers. 1963. The systematic position of certain hawks in the genus Buteo. Auk 80:417-446.

Klicka J., AND R. M. ZinK. 1999. Pleistocene effects on North American songbird evolution. Proceedings of the Royal Society of London B 266:695-700.

Kruckenhauser, L., E. Haring, W. Pinsker, M. Riesing, H. WinKLeR, M. Wink, AND A. Gamauf. 2004. Genetic vs. morphological differentiation of Old World buzzards (genus Buteo, Accipitridae). Zoologica Scripta 33:197-211.

LATHAM, J. 1790. Supplement to the general synopsis of birds. Leigh and Southeby, London.

MAGNUSSON, W. E. 1983. Use of discriminant function to characterize Ruffed Grouse drumming sites in Georgia: a critique. Journal of Wildlife Management 47:1151-1152.

Marshall, L. G., S. D. WebB, J. J. SePKOSKi JR., AND M. Raup. 1982. Mammalian evolution and the great American interchange. Science 215:1351-1357.

Meyer de Schauensee, R. 1966. The species of birds of South America and their distribution. Livingston, Wynnewood, PA.
MilleR, W. D., AND L. GRISCOM. 1921. Description of proposed new birds from Central America, with notes on some other littleknown forms. American Museum Novitates 25.

MillsaP, B. A. 1986. Biosystematics of the Gray Hawk, Buteo nitidus (Latham). M.Sc. thesis, George Mason University, Fairfax, VA.

Patten, M. A., And P. UnitT. 2002. Diagnosability versus mean differences of Sage Sparrow subspecies. Auk 119:26-35.

Rich, P. V., AND T. H. Rich. 1983. The Central American dispersal route: biotic history and paleogeography, p. 12-34. In D. H. Jenzen [ED.], Costa Rican natural history. University of Chicago Press, Chicago.

Ridgely, R. S. 1976. A guide to the birds of Panama. Princeton University Press, Princeton, NJ.

Riesing, M. J., L. Kruckenhauser, A. Gamauf, and E. Haring. 2003. Molecular phylogeny of the genus Buteo (Aves: Accipitridae) based on mitochondrial marker sequences. Molecular Phylogenetics and Evolution 27:328-342.

Schlegel, H. 1862. Asturinae. Muséum d'Histoire Naturelle des Pays-Bas, Revue Méthodique et Critique des Collections Déposées dans cet Établissement, vol. 2, monograph 6. Leyden, Netherlands.

Sibley, C. G., And B. L. Monroe. 1990. Distribution and taxonomy of birds of the world. Yale University Press, New Haven, CT.

SLuD, P. 1964. The birds of Costa Rica. Bulletin of the American Museum of Natural History 128.

SNyder, N. F. R., AND J. W. WiLey. 1976. Sexual size dimorphism in hawks and owls in North America. Ornithological Monographs 20.

SoKal, R. R., AND F. J. Rohlf. 1981. Biometry. W. H. Freeman, San Francisco.

Stiles, F. G., AND A. F. Skutch. 1989. A guide to the birds of Costa Rica. Comstock, Ithaca, NY.

Stresemann, E., AND D. Amadon. 1979. Falconiformes, p. 271-425. In E. Mayr and G. W. Cottrell [EDS.], Checklist of birds of the world, vol. 1. Museum of Comparative Zoology, Harvard University, Cambridge, MA.

SYSTAT. 2009. Statistics I, II, III, and IV. SYSTAT Software, Inc., Chicago.

VAN DER Hammen, T. 1974. The Pleistocene changes of vegetation and climate in tropical South America. Journal of Biogeography $1: 3-26$.

Van Rossem, A. J. 1930. A northwestern race of the Mexican Goshawk. Condor 32:303-304.

WINKER, K. 2009. Reuniting phenotype and genotype in biodiversity research. BioScience 59:657-665. 
APPENDIX A. Specimens of B. n. nitidus and B. n. plagiatus examined for this paper. AMNH, American Museum of Natural History; FMNH, Field Museum of Natural History; KMNH, Kansas Museum of Natural History; MCZ, Museum of Comparative Zoology; UDMNH, University of Delaware Museum of Natural History; USNM, National Museum of Natural History, Smithsonian Institution.

Buteo $n$. nitidus $(n=141)$. Adults $(n=93)$. AMNH $(n=38): 12439$ 471006, 470997, 798685, 470994, 471001, 4290, 804555, 71377, 130615, $99914,97912,804556,471002,288192,241523,34741,471012,471013$ $136867,471094,186658,183059,44873,471011,44872,73205,471010$ 471004, 177057, 44874, 470993, 277582, 131440, 97913, 71378, 30874, and 308956. FMNH $(n=21): 190720,260977,81434,101362,101543$, 102458, 190719, 260979, 399311, 32164, 45003, 100816, 101359, 101361 102459, 108036, 123846, 260978, 101597, 295951, and 190718. MCZ $(n=6): 155131,14729,155133,117983,155128$, and 22987. USNM $(n=$ 28): 425426, 448642, 454973, 372362, 384589, 388451, 90156, 512907, 386709, 400145, 400146, 409273, 409274, 409275, 457586, 532976, $383341,372363,410529,107208,401202,391851,369485,368486$, $368484,410530,470435$, and 513820. Juveniles $(n=48)$. AMNH $(n=17): 471007,471005,471000,236509,121441,97910,241522$ 313391, 470995, 34635, 44875, 107111, 471008, 471003, 470996, 73206, and 97911. FMNH $(n=14)$ : 34308, 96306, 101363, 75239, 101022, $295229,190721,57666,100815,101360,101514,101556,217630$, and 295952. MCZ $(n=1): 155132 . \mathbf{U S N M}(n=16): 368485,383342,107210$, 383343, 386708, 477559, 400147, 470613, 406424, 372365, 107209, $121084,372364,516149,391853$, and 391852

Buteo $n$. plagiatus $(n=264)$. Adults $(n=184)$. AMNH $(n=57)$ : 793529, illegible, 80780, 80787, 91154, 91153, 80791, 80783, 92836, $750309,389161,393624,143747,103287,389162,775878,104614,104627$, 104615, 470980, 775880, 470983, 352735, 106204, 750357, 352729, $448072,36454,91159,80789,80784,92017,80792,91151,91148,352730$ $91147,80782,91150,750358,80785,56567,393618,393623,103078$, 143745,393622 , 393616, 44879, 470978, 470981, 352374, 352732, 104616,
366752, 470985, and 388697. FMNH $(n=34): 183312,130639,156947$, $21838,111179,111182,124188,126978,126979,126980,126982,126983$ $370953,100940,102539,124185,124187,183313,96303,100273,100274$, $100276,156948,95182,100939,124189,124190,126977,96304,120827$, $183311,208620,96305$, and 124186. KMNH $(n=7): 36053,23711,23209$ 23709, 32629, 32630, and 23710. MCZ $(n=41): 224765,104308,224767$ 224777, 224773, 505931, 205939, 252671, 224771, 48460, 48461, 328371, 193510, 40125, 163185, 163184, 46525, 100906, 65209, 317886, 104039 $317887,309370,224763,205989,206010,252670,48463,48462,48459$, 48458, 224775, 224764, 224776, 924240, 157944, 145644, 73091, 102293 , 328516, and 40124. UDMNH $(n=1)$ : 55127. USNM $(n=44): 155624$, $482018,588468,34002,129321,157371,361432,302647,89770,120287$, 302646, 334764, 349524, 189117, 57869, 167724, 370556, 370559, 69072, 79803, 437507, 363451, 371343, 155623, 129322, 564795, 30538, 199376, 199368, 396524, 155625, 89769, 90002, 370553, 370554, 370557, 370558, 437506, 57868, 150646, 155626, 155627, 120286, and 189116. Juveniles $(n=80)$. AMNH $(n=38): 80790,80781,80779,56565,406613,143744$, 393617, 393620, 470987, 470990, 105329, 776251, 470984, 470986, $352733,470982,56566,91149,91152,406612,143748,103080,393619$ $393625,101091,104617,104613,775881,470703,44876,44878,776249$, $775879,470989,105328,44877,470988$, and. 776250 . FMNH $(n=17)$ : 100275, 22396, 102540, 102787, 120826, 208619, 22395, 111180, 111181, $111183,124192,126981,22397,110216,189782,370954$, and 95183 KMNH $(n=5): 35611,32631,36417,28908$, and 40415. MCZ $(n=4)$ : 206017, 206470, 286358, and 73092. UDMNH $(n=1): 38476$. USNM $(n=15): 42775,155632,193864,459493,50772,158530,129323,132138$ $35060,155628,155633,185338,370555,334763$, and 57856 .

APPENDIX B. Recordings of alarm calls of Buteo n. nitidus and B. n. plagiatus evaluated for this study. XC, www.xeno-canto.org; ML, Macaulay Library, Cornell Laboratory of Ornithology; Sandoval, private collection of L. Sandoval. For every record we provide collection and number, country, state/province, and locality; records are arranged alphabetically by country by taxon.

Buteo n. nitidus: XC 53323, Bolivia, Santa Cruz, Estancia Caparu; XC 1916, Bolivia, Noel Kempff-Mercado NP; XC 7052, Brazil, Pernambuco, Mata de Aldeia; XC 8755, Brazil, Ceará, Serra de Baturité; ML 32486, Brazil, Amazonas, 80.0 km N of Manaus; ML 127971, Brazil, Alagoas, Usina Serra Grande, Engenho Coimbra; ML 127606, Brazil, Amazonas, $8.0 \mathrm{~km}$ from ENE of Careiro do Castanho, Fazenda Toshiba; XC 12093 , Brazil, Pará, Serra dos Carajás; ML 126664, Brazil, Pará, Floresta Nacional de Carajas, Salobo Road; ML 127718, Brazil, Amazonas, Projeto de Assentimento Puxurizal; ML 68076, Colombia, Magdalena, Santa Marta Mts.; XC 18189, Colombia, Antioquía, Cañón del Río Claro; XC 16312, Colombia, Antioquía, La Cueva del Cóndor; XC 4, Ecuador, Guayas, Cerro Blanco Reserve; XC 55594, Paraguay, Alto Paraguay, Kamba Aka; XC 35185, Peru, Cuesta del Pitón; XC 47556, Peru,
Madre de Dios, Oceanía; ML 58991, Venezuela, Táchira, Río Navay, San Joaquín de Navay; ML 58987, Venezuela, Bolívar, El Palmar; ML 58985, Venezuela, Aragua, Maracay, lake path, east of paved road; XC 9927, Venezuela, Bolívar, Río Caura S of Maripa; ML 58984, Venezuela, Aragua, Ocumare de la Costa; ML 58990, Venezuela, Táchira, near La Tendida (or Pozuelos); ML 58986, Venezuela, Zulia, Misión Río Tucuco; ML 112269, Venezuela, Bolívar, Campamento Río Grande.

B. n. plagiatus: Sandoval 001, Costa Rica, Heredia, Getsemaní; ML 89521, Mexico, Colima, 23.0 km NW of Manzanillo; ML 4199, Mexico, Yucatán, 6.0 km E of Piste; XC 30621, Mexico, Nayarit, La Bajada; ML 4198, Mexico, Sinaloa, $116.8 \mathrm{~km}$ S of Culiacán; XC 10888, Nicaragua, El Rama; ML 140236, USA, Arizona, E of Harshaw Canyon, Patagonia ML 109002, USA, Arizona, $4.0 \mathrm{~km} \mathrm{~W}$ of Arivaca, along Arivaca Creek. 